Pesq. Vet. Bras. 37(3):221-226, março 2017 DOI: $10.1590 /$ S0100-736X2017000300004

\title{
The use of Eucalyptus staigeriana nanoemulsion for control of sheep haemonchosis ${ }^{1}$
}

\author{
Wesley L.C. Ribeiro², Ana L.F. Camurça-Vasconcelos ${ }^{2,3}$, Jessica M.L. dos Santos², Iara \\ T.F. Macedo ${ }^{2}$, Juliana de C. Ribeiro ${ }^{2}$, Erick F. de Oliveira ${ }^{4,5}$, Haroldo C.B. de Paula ${ }^{4}$ \\ and Claudia M.L. Bevilaqua ${ }^{2 *}$
}

\begin{abstract}
Ribeiro W.L.C., Camurça-Vasconcelos A.L.F., Santos J.M.L., Macedo I.T.F., Ribeiro J.C., Oliveira E.F., Paula H.C.B. \& Bevilaqua C.M.L. 2017. The use of Eucalyptus staigeriana nanoemulsion for control of sheep haemonchosis. Pesquisa Veterinária Brasileira 37(3):221-226. Programa de Pós-Graduação em Ciências Veterinárias, Faculdade de Veterinária, Universidade Estadual do Ceará, Avenida Dr. Silas Munguba 1700, Fortaleza, CE 60714-903, Brazil. E-mail: bevilaqua.uece@gmail.com

Sustainable control of gastrointestinal nematodes (GIN) in small ruminants has been based on the use of alternative methods, including targeted selective treatment, such as FAMACHA. Another GIN control alternative is the use of herbal medicines, although in many cases their use is based on empirical knowledge. Biopolymer nanoformulations has been investigated to maximize the essential oil effects against sheep gastrointestinal nematodes. The aim of the present study was to combine a Eucalyptus staigeriana essential oil nanoemulsion (EsNano) with FAMACHA as an alternative control for sheep haemonchosis. The study was performed over six months at a commercial sheep farm located in a semiarid region of Northeast Brazil. Initially, a fecal egg count reduction test (FECRT) in sheep with levamisole, ivermectin and oxfendazole in sheep was performed used to determine the most effective anthelmintic to use as the positive control. Levamisole has been selected because it showed efficacy superior to 95\%. EsNano was obtained and then its physicochemical properties were characterized. The average ( \pm SE) size of the particles in the nanoemulsion was $276.8( \pm 12.3) \mathrm{nm}$ with bimodal distribution and polydispersity. Nine visits were performed, from April to September 2013, with an interval of 17 days. One hundred sixty-two male and female sheep were divided into three groups $(n=54$ each) and were treated when FAMACHA score was 3, 4, or 5: G-EsNano $250 \mathrm{mg} \mathrm{kg}^{-1}$ EsNano; G-Lev 7.5 $\mathrm{mg} \mathrm{kg}^{-1}$ levamisole (positive control), and G-Neg was not treated (negative control). Feces from sheep were collected to quantify the number of eggs per gram of feces (epg) and to identify nematode genera. Sheep weight gain was monitored. The epg data for each group and the average sheep weight gains were analyzed by variance analysis and compared with the Tukey's test $(P<0.05)$. Significant difference between the number of animals treated with EsNano and levamisole was not observed in any visit $(P>0.05)$. The epg variation was similar in the G-EsNano and G-Lev groups on visits $(P>0.05)$, except the second and fifth evaluation in the epg groups were significantly different $(P<0.05)$. Haemonchus spp. was the most prevalent nematode. There was no significant weight gain in any of the treated groups $(P<0.05)$. The combination of phytotherapy and FAMACHA can be an alternative to minimize the use of synthetic anthelmintics to control resistant GIN populations of small ruminants.
\end{abstract}

INDEX TERMS: Small ruminants, Haemonchus contortus, FAMACHA, essential oil, chitosan.

\footnotetext{
${ }^{1}$ Received on March 17, 2016.

Accepted for publication on September 30, 2016

${ }^{2}$ Programa de Pós-Graduação em Ciências Veterinárias, Faculdade de Veterinária, Universidade Estadual do Ceará, Av. Dr. Silas Munguba 1700, Fortaleza, CE 60714-903, Brazil. *Corresponding author: bevilaqua.uece@ gmail.com
}

\footnotetext{
${ }^{3}$ Curso de Medicina Veterinária, Faculdade Terra Nordeste, Rua Coronel Correa 1119, Caucaia, CE 61603-005, Brazil.

${ }^{4}$ Departamento de Química Analítica e Físico-Química, Universidade Federal do Ceará, Av. Mister Hull s/n, Fortaleza, CE 60445-900, Brazil.

${ }^{5}$ Department of Food Science and Technology, University of California, Davis, CA 95616, USA.
} 
RESUMO.- [Uso da nanoemulsão de Eucalyptus staigeriana no controle da hemoncose em ovinos.] 0 controle sustentável de nematoides gastrintestinais (NGI) em pequenos ruminantes tem sido baseado na utilização de métodos alternativos, incluindo o tratamento alvo-seletivo, tal como o FAMACHA. Outra alternativa de controle de NGI é o uso de plantas medicinais, embora, em muitos casos, a sua utilização seja baseada no conhecimento empírico. Nanoformulações biopoliméricas-tem sido investigadas para maximizar os efeitos de óleos essenciais sobre nematoides gastrointestinais em ovinos. 0 objetivo do presente estudo foi combinar a nanoemulsão do óleo essencial de Eucalyptus staigeriana (EsNano) com o método FAMACHA como uma alternativa para o controle da hemoncose em ovinos. Este estudo foi realizado ao longo de seis meses em uma fazenda comercial de ovinos localizada em uma região semiárida do Nordeste do Brasil. Inicialmente, um teste de redução da contagem de ovos nas fezes (FECRT) em ovinos com levamisol, ivermectina e oxfendazole foi realizado para determinar o anti-helmíntico mais eficaz, para posterior uso como controle positivo. Levamisol foi selecionado porque mostrou eficácia superior a 95\%. EsNano foi obtido e, em seguida, as suas propriedades físico-químicas foram caracterizadas. 0 tamanho médio $( \pm \mathrm{SE})$ das partículas na nanoemulsão foi $276,8( \pm 12,3) \mathrm{nm}$, com distribuição bimodal e polidispersividade. Foram realizadas nove visitas, de abril a setembro de 2013, com um intervalo de 17 dias. Cento e sessenta e dois ovinos machos e fêmeas foram divididos em três grupos ( $\mathrm{n}=54$ cada) e foram tratados quando o FAMACHA foi 3, 4 ou 5: G-EsNano $250 \mathrm{mg} \mathrm{kg}^{-1}$ EsNano; G-Lev $7,5 \mathrm{mg} \mathrm{kg}^{-1}$ de levamisol (controlo positivo), e G-Neg não foi tratado (controle negativo). As fezes dos ovinos foram coletadas para quantificar o número de ovos por grama de fezes (opg) e identificar os gêneros de nematóides. 0 ganho de peso de ovinos foi monitorado. Os dados do opg de cada grupo e os ganhos de peso médio dos ovinos foram analisados por análise de variância e comparadas com o teste de Tukey $(P<0,05)$. Diferença significativa entre o número de animais tratados com EsNano e levamisol não foi observada em nenhuma visita $(P>0,05)$. A variação opg foi semelhante para os grupos G-EsNano e G-Lev nas vistas $(P>0,05)$, excetuando a segunda e quinta avaliação em que os opg dos grupos foram significativamente diferentes $(P>0,05)$. 0 nematoide Haemonchus spp. foi o mais prevalente. Não houve aumento significativo de peso em qualquer um dos grupos tratados $(P>0,05)$. Assim, a combinação de fitoterapia e FAMACHA pode ser uma alternativa para minimizar o uso anti-helmínticos sintéticos para controlar populações resistentes NGI em pequenos ruminantes.

TERMOS DE INDEXAÇÃO: Pequenos ruminantes, Haemonchus contortus, FAMACHA, óleo essencial, quitosana.

\section{INTRODUCTION}

Gastrointestinal nematodes (GIN) of small ruminants cause severe pathology and major economic losses in sheep and goat farming, particularly in tropical and subtropical areas worldwide (Akkari et al. 2013). GIN control programs primarily rely on a combination of animal management practices and the use of anti-parasitic drugs (Lifschitz et al. 2014). However, indiscriminate use of anthelmintics (AH) is considered to be inefficient, costly and harmful to herds, as it favors rapid selection of GIN-resistant populations to all available AH classes (Molento et al. 2004). Anthelmintic resistance has already been reported for monepantel, the latest anthelmintic released on the market (Scott et al. 2013, Van den Brom et al. 2015). Therefore, the development of sustainable, environmentally acceptable methods of nematode control is crucial.

Targeted selective treatment (TST) was proposed to reduce the use of $\mathrm{AH}$ and thereby help maintain GIN populations in refugia, i.e., larvae and/or adults that remain without treatment continue to harbor sensitivity alleles (Cabaret 2008). FAMACHA is considered a TST approach for reducing parasite chemical exposure (Kenyon et al. 2009). The method is based on the correlation between eye mucous color and hematocrit values, which is used to identify animals that are able to withstand infections by Haemonchus contortus (Vilela et al. 2012).

Research on plants to obtain new bioactive compounds has also been encouraged (Acharya et al. 2014). Elucidating the mechanisms governing the anthelmintic activity of plants against parasites of small ruminants is important for the development of sustainable strategies of helminth control (Sandoval-Castro et al. 2012). Eucalyptus spp. (Myrtaceae) is native to Australia and is mainly cultivated for use by the paper, pharmaceutical and cosmetic industries (Hasegawa et al. 2008). The nematicide action of Eucalyptus staigeriana essential oils (EsEO) was described previously (Macedo et al. 2010, Mesquita et al. 2013).

To protect the chemical constituents and maximize the nematicidal effect of EsEO, nanoencapsulation techniques employing chitosan have been investigated (Ribeiro et al. $2013,2015)$. The emulsion technology is generally applied for the encapsulation of bioactive compounds in aqueous solutions through the production of nanoemulsions (Shahavi et al. 2015). Chitosan is a widely used biopolymer in the biomedical area and offers several advantages, and these include its ability to control the release of active compounds, low toxicity and high biodegradability (Dash et al. 2011).

The study aimed to assess the ability of E. staigeriana essential oil nanoemulsion (EsNano) combined with FAMACHA to control haemonchosis in a sheep management system.

\section{MATERIALS AND METHODS}

Eucalyptus staigeriana essential oil nanoemulsion (EsNano). The EsEO was purchased from Avondale Essências (Braganey, Brazil) and the sample used in the present study was similar to that used by Ribeiro et al. (2015). The main chemical constituents were geranial $(16.0 \%)$, geraniol (14.8\%), methyl geranate $(11.0 \%)$, geranyl acetate $(9.2 \%)$ and limonene $(7 \%)$ (Ribeiro et al., 2015).

Chitosan powder, with $92 \%$ deacetylation was purchased from Polymar S/A (Fortaleza, Brazil). The EsNano was obtained according to the methodology described by Ribeiro et al. (2015) and the macroscopic characteristics of EsNano stability were observed over $72 \mathrm{~h}$. 
The EsNano, EsEO and 1\% chitosan solution were subjected to thin layer chromatography and characterized by infrared spectroscopy (FTIR) using the model 8300 (Shimadzu Corporation, Japan).

The size and distribution of nanoparticles in solution were determined using a beam of red light with a wavelength of 633 $\mathrm{nm}$ and angulation of $175^{\circ}$ (ZetaSizer 3600, Malvern, United Kingdom). For this purpose, EsNano samples were dissolved in deionized water to a final concentration of $0.1 \%(\mathrm{w} / \mathrm{v})$ and were left to stir for $24 \mathrm{~h}$. These analyses were performed in triplicate.

EsNano samples were prepared up to $72 \mathrm{~h}$ prior to each administration. The size distribution of the nanoparticles and macroscopic characteristics of all samples were evaluated to standardize the EsNano physicochemical properties.

Study area. The study was conducted on a sheep farm in the municipality of Solonópole $\left(5^{\circ} 46.003^{\prime} \mathrm{S}\right.$ and $\left.38^{\circ} 51.000^{\prime} \mathrm{W}\right)$, a semiarid region of the Ceará State, Brazil.

The climate is typically hot, semi-arid tropical with average temperatures ranging from 26 to $28^{\circ} \mathrm{C}$. The annual rainfall is $717.1 \mathrm{~mm}$ with rains concentrated between January and April. The vegetation is predominantly formed by open shrubby Caatinga and dense shrubby Caatinga (Ceará 2011).

The mean rainfall at the Solonópole Rainfall Measuring Station during the study period was provided by Fundação Cearense de Meteorologia e Recursos Hídricos.

Ethics committee on animal welfare. The protocol was approved by the ethics committee for animal use of Universidade Estadual do Ceará (number: 10461354-8/65).

Fecal egg count reduction test. The sheep were originated from crosses between Dooper, Santa Inês and Somalis races. The animals were kept under semi-extensive rearing management protocols, fed on native pastures and supplemented with mineral salt (Ovinofós, Tortuga, São Gonçalo do Amarante, Brazil).

A fecal egg count reduction test (FECRT) was used to determine the most effective anthelmintic to use as the positive control. Therefore, thirty sheep with egg counts per gram of feces (epg) greater than 250 were selected and randomly divided into three groups $(\mathrm{n}=10$ each) for treatment with the anthelmintic classes that are most widely used by producers from the region: G1: $200 \mu \mathrm{g} \mathrm{kg}^{-1}$ ivermectin (Ivomec, Merial Saúde Animal, Paulínia, Brazil); G2: 7.5mg kg-1 levamisole (Ripercol, Fort Dodge Saúde Animal LTDA, Campinas, Brazil) and G3: $5 \mathrm{mg} \mathrm{kg}^{-1}$ oxfendazole (Systamex, Schering-Plough Animal Health, Guarulhos, Brazil). The treatments were administered orally in a single dose. The fecal samples were collected at days 1 and 14 post-treatment for epg estimation. Larvae from a pool of feces from each group were cultured to identify the nematode genera. Larval identification was based on Ueno \& Gonçalves (1998).

After performing the FERCT, levamisole was selected as the positive control of the anthelmintic activity in the field.

Anthelmintic activity in the field. One hundred sixty-two male and female sheep aged seven months to six years were identified and divided into three groups ( $n=54$ each) based on epg, age, sex and body weight. G EsNano: $250 \mathrm{mg} \mathrm{kg}^{-1}$ EsNano, corresponding to $0.76 \mathrm{ml}$ of EsNano per kg of bodyweight; G-Lev: $7.5 \mathrm{mg}$ $\mathrm{kg}^{-1}$ levamisole (positive control) (Ripercol, Zoetis, São Paulo, Brazil) and G-Neg: sheep were untreated.

Nine visits with 17 days in between were made from April and September 2013. The color of the ocular mucous membranes of each sheep was examined and classified into one of five categories according to the FAMACHA eye color chart (Vatta et al. 2001). Animals with a FAMACHA score of 3,4 or 5 were treated according to their respective group.

The fecal samples were collected directly from the rectums of all sheep in each experimental group to perform epg and larvae from a pool of feces from each group were cultured to identify the nematode genera. The epg was performed using the McMaster technique (Gordon \& Whitlock 1939).

Additionally, the animals were weighed on the first and last visits to assess their weight gain. Based on dental age, the sheep were categorized into five groups $(<1.5 ; 1.5$ to $3 ; 3$ to $4 ; 4$ to 5 and $>5$ years) (Sandoval-Júnior 2011).

Statistical analysis. The arithmetic mean \pm standard error (SE) of the mean EsNano particle size were calculated.

The FERCT efficacy was calculated using the following formula: FERCT $=100 \times(1-[\mathrm{T} 2 / \mathrm{T} 1])$, where $\mathrm{T} 1$ and $\mathrm{T} 2$ represent fecal eggs counts in the treated groups at days -1 and 14 post-treatment, respectively (Kochapakdee et al. 1995), and 95\% confidence intervals (CI) were estimated using the BootStreat 1.0 software (Cabaret 2014).

Chi-square tests were conducted to compare the number of animals treated with levamisole and EsNano for each visit using the GraphPad Prism 5.0 program (GraphPad Software, Inc., California, USA. A $p$-value of $<0.05$ was considered significant.

The epg data for each group were log transformed $(\log 10[\mathrm{x}+1])$, analyzed with variance analysis (ANOVA) and compared with Tukey's test $(P<0.05)$ using the GraphPad Prism 5.0 program. The mean epgs for each group at different visits were presented as the arithmetic mean \pm SE.

The mean sheep weight gains were analyzed with ANOVA and compared by the Tukey's test $(P<0.05)$ using the GraphPad Prism 5.0 program.

\section{RESULTS}

The infrared spectroscopy has demonstrated that the chitosan main bands (Fig.1) appeared at $1643 \mathrm{~cm}^{-1}$ (carbonyl groups of partially acetylated groups), $1425 \mathrm{~cm}^{-1}$ (angular deformation of $\mathrm{CH}_{2}$ ), $1370 \mathrm{~cm}^{-1}$ (C-N axial deformation) and $1084 \mathrm{~cm}^{-1}$ (C-O-C glycosidic bonds) (Robles et al. 2013, Herculano et al. 2015). The main characteristic bands of EsEO can be observed at 2922, 1742, 1670, 1438, 1377, 1227 and $1146 \mathrm{~cm}^{-1}$. Most signals are referred to $\mathrm{CH}$ and $\mathrm{C}=\mathrm{O}$ aldehyde groups, as well to methyl and methylene groups of limonene and citronelal. The nanoemulsion exhibits overlapped bands of both chitosan and EsEO, providing evidence of a successful encapsulation.

The nanoemulsion was formed almost immediately after the organic (chitosan solution) and inorganic (EsE0) phase come into contact. The EsEO concentration in the nanoemulsion was $36.4 \%(\mathrm{v} / \mathrm{v})$. Physicochemical analyses of the resulting nanoemulsion particles revealed a mean size $( \pm$ SE) of $276.8( \pm 12.3) \mathrm{nm}$ with bimodal distribution and polydispersity in all samples. The nanoemulsion was white, with a milky consistency and could flow through an oral dosing pistol. No phase separation was visually observed after $72 \mathrm{~h}$.

The efficacy $( \pm \mathrm{CI})$ of ivermectin, levamisole and oxfendazole in the FERCT was 55\% (-7 - 89), 97\% (88 - 101) and $11 \%(-66-55)$, respectively. Based on these results, levamisole was selected as the positive control. The most prevalent helminth in all of the larval cultures pre- and post-treatment was Haemonchus spp. (85.5\%) followed by Trichostrongylus spp. (8.8\%), Oesophagostomum spp. (4.2\%) and Cooperia spp. (0.6\%).

The percentage of animals treated with levamisole and EsNano based on FAMACHA is presented in Figure 2. There 
was no significant difference in the number of animals treated in the groups at all visits $(P>0.05)$.

The curves of the mean epg variations of the G-EsNano, G-Lev and G-Neg groups are presented in Figure 3. The tendency of epg variation was similar for G-EsNano and G-Lev, except on the second (April 22th) and fifth (June 12th) visits, wherein the mean epg in G-EsNano was significantly higher $(P<0.05)$. The mean epg of G-EsNano and G-Neg was signicantly different except in the first (April 5th), second (April 22th), fourth (May 26th) and eighth (August 29th) visits $(P<0.05)$.

A similar percentage of nematode genera were recovered from sheep in all of the groups after nine evaluation visits. Haemonchus spp. was the most prevalent genus with a mean of $79 \%, 80.1 \%$ and $82.3 \%$ for G-EsNano, G-Lev and G-Neg, respectively. The prevalence of Trichostrongylus spp. and Oesophagostomum spp. was not significantly different among the three groups. Cooperia spp. was the less prevalent genus.

The sheep weight gains in the groups are presented in Table 1 . There were no significant differences in weight

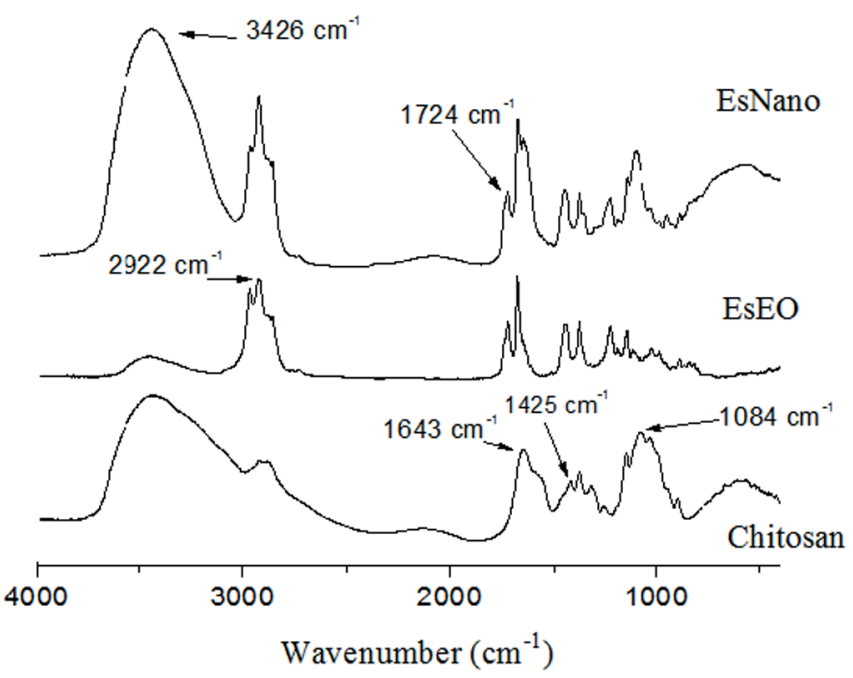

Fig.1. Infrared spectra of the sample of Eucalyptus staigeriana nanoemulsion (EsNano), Eucalyptus estaigeriana essential oil (EsE0) and 1\% chitosan solution.

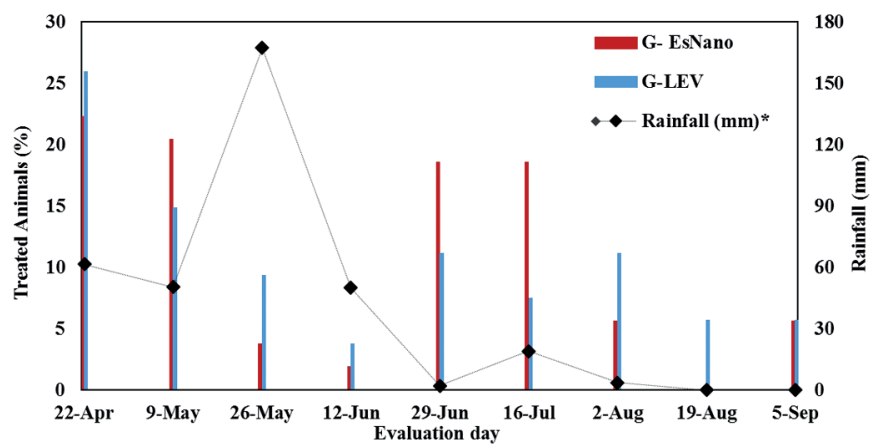

Fig.2. Sheep (\%) with EsNano (FAMACHA scores 3, 4 or 5) treated with Eucalyptus staigeriana nanoemulsion (G-EsNano; 250 mg kg-1) or levamisole (G-Lev; $7.5 \mathrm{mg} \mathrm{kg-1)} \mathrm{in} \mathrm{a} \mathrm{semiarid} \mathrm{re-}$ gion of Northeastern Brazil from April to September 2013. *A specific point on the rainfall curve refers to the accumulated rainfall $(\mathrm{mm})$ on day 17 before each visit.

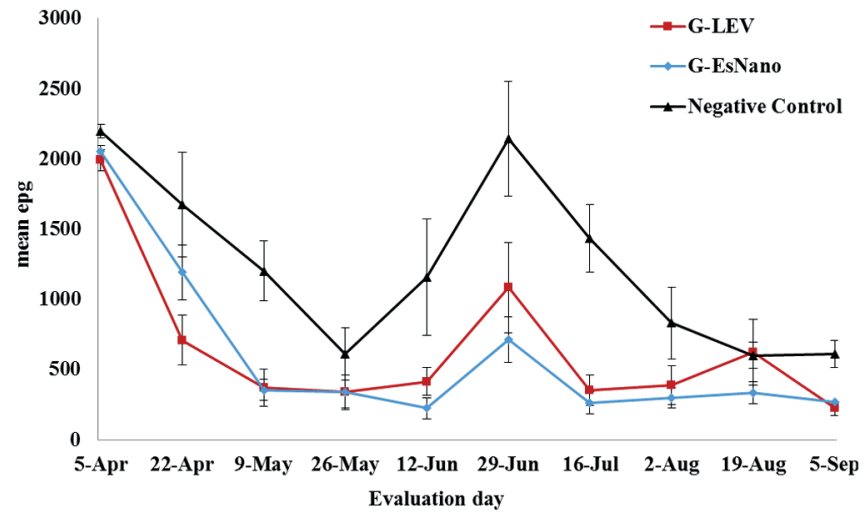

Fig.3. The mean (standard error) egg per gram (epg) of feces in sheep treated with Eucalyptus staigeriana nanoemulsion (G-EsNano; $250 \mathrm{mg} \mathrm{kg}$-1) or levamisole (7.5 mg kg-1) and in untreated animals (G-Neg) in a semi-arid region of Northeastern Brazil from April to September 2013. The significance level was $5 \%$.

Table 1. The mean ( \pm standard error) sheep weights at the beginning and at the end of the treatment with Eucalyptus staigeriana nanoemulsion (G-EsNano) and levamisole (G-LEV) and in untreated animals (G-Neg) from April to September 2013

\begin{tabular}{|c|c|c|c|}
\hline \multirow[t]{2}{*}{$\operatorname{Age}^{1}$ (year) } & \multirow[t]{2}{*}{ Group } & \multicolumn{2}{|c|}{ Weight (kg) } \\
\hline & & Initial & Final \\
\hline \multirow[t]{3}{*}{$<1.5$} & G-EsNano & $22.6 \pm 1.1^{\text {Aa }}$ & $25.7 \pm 1.4^{\mathrm{Aa}}$ \\
\hline & G-Lev & $24.3 \pm 1.7^{\mathrm{Aa}}$ & $30.3 \pm 2.4^{\mathrm{Aa}}$ \\
\hline & G-Neg & $23.3 \pm 0.9^{\mathrm{Aa}}$ & $27.3 \pm 0.9^{\mathrm{Aa}}$ \\
\hline \multirow[t]{3}{*}{$1.5-3$} & G-EsNano & $24 \pm 0.8^{\mathrm{Bb}}$ & $26.5 \pm 1.7^{\mathrm{Bb}}$ \\
\hline & G-Lev & $32.6 \pm 1.5^{\mathrm{Bb}}$ & $33.5 \pm 2.4^{\mathrm{Bb}}$ \\
\hline & G-Neg & $28.1 \pm 1.3^{\mathrm{Bb}}$ & $29.9 \pm 1.8^{\mathrm{Bb}}$ \\
\hline \multirow[t]{3}{*}{$3-4$} & G-EsNano & $31 \pm 0.4^{\mathrm{Cc}}$ & $34.8 \pm 3^{\mathrm{Cc}}$ \\
\hline & G-Lev & $37.1 \pm 1.7^{\mathrm{cc}}$ & $36.8 \pm 2.2^{\mathrm{Cc}}$ \\
\hline & G-Neg & $32 \pm 0.9^{\mathrm{cc}}$ & $34.7 \pm 1.3^{\mathrm{Cc}}$ \\
\hline \multirow[t]{3}{*}{$4-5$} & G-EsNano & $34 \pm 1.5^{\mathrm{Dd}}$ & $38 \pm 1.5^{\mathrm{Dd}}$ \\
\hline & G-Lev & $34 \pm 1.6^{\mathrm{Dd}}$ & $36.2 \pm 1.5^{\mathrm{Dd}}$ \\
\hline & G-Neg & $33 \pm 1.8^{\mathrm{Dd}}$ & $34 \pm 2.4^{\mathrm{Dd}}$ \\
\hline \multirow[t]{3}{*}{$>5$} & G-EsNano & $35.7 \pm 1.6^{\mathrm{Ee}}$ & $36.3 \pm 1.5^{\mathrm{Ee}}$ \\
\hline & G-Lev & $36.6 \pm 1.9^{\mathrm{Ee}}$ & $37.8 \pm 2.1^{\mathrm{Ee}}$ \\
\hline & G-Neg & $37.8 \pm 1.7^{\text {Ее }}$ & $38.2 \pm 2.9^{\mathrm{Ee}}$ \\
\hline
\end{tabular}

The capital letters indicate comparisons of the means in the rows, and the lowercase letters indicate comparisons of the means between groups of the same age. The different letters indicate significant differences $(\mathrm{P}<0.05) .{ }^{1}$ Estimated age according to changes in the teeth of the animals.

gain among the ages of animals in the same treatment group before and after treatment $(P<0.05)$.

\section{DISCUSSION}

The adoption of alternative methods for GIN control must be based on the implementation of strategies to address anthelmintic resistance control while considering not only the parasite biology but also farm decisions and whole management decisions (Morgan \& Van Dijk 2012). Therefore, new alternatives for controlling helminths in small ruminants have been widely tested, such as using phytotherapy and FAMACHA (Vieira et al. 2014).

The EsEO with limonene as major oil component (28.82\%) showed effect of $76.57 \%$ against goat gastroin- 
testinal nematodes (Macedo et al. 2010) and the EsEO hydrogel presented effect of $83.75 \%$ against sheep abomasal nematodes (Mesquita et al. 2013).

A new area of study that focuses on the use of biopolymers for encapsulation of essential oils has been developed (Paula et al. 2011). Chitosan is a biopolymer that is suitable for biomedical applications such as encapsulation matrices due to its low toxicity and excellent biodegradability (Balan $\&$ Verestiuc 2014). Therefore, chitosan was selected as the encapsulating matrix for EsEO to be evaluated against sheep haemonchosis.

The preparation of chitosan-based nanoemulsions for encapsulating volatile compounds has been proposed to promote active protection and to maximize the biological effects of essential oils (Paula et al. 2011). Nanoemulsions are versatile and can be prepared via numerous different aqueous solutions, surfactants and oil constitutes (Underwood \& Van Eps 2012). In this study, the physicochemical characteristics of EsNano were similar to the nanoemulsion used in in vitro tests on Haemonchus contortus (Ribeiro et al. 2015).

Although nanostructured essential oils have been developed for use against GIN small ruminants (Ribeiro et al. 2014, Grando et al. 2015), validation of these products requires an assessment of $\mathrm{AH}$ effects for a prolonged period in sheep. The present study validated the anthelmintic effect of EsNano when combined with FAMACHA in the dry season.

FAMACHA is the TST most used by sheep and goat farmers in Northeast Brazil. Furthermore, Haemonchus spp. was the most prevalent nematode in larval cultures, supporting the application of FAMACHA (Bath \& Van Wyk 2009). Although $H$. contortus infection persisted in the herd, the selective treatment strategy significantly reduced the use of $\mathrm{AH}$, yielding significant health and economic benefits (Molento et al. 2009). Additionally, the FAMACHA method is able to identify sheep that are at risk of reducing the selection pressure for anthelmintic resistance. In this study, using FAMACHA, the highest percentage of animals treated per visit was $26 \%$ for the G-Lev, which is important for maintaining nematode populations in refugia (Cabaret, 2008). Furthermore, FAMACHA is particularly important in areas with a prolonged dry season, when the survival of free-living stages in the pasture is low or null, thus decreasing the proportion of nematodes in refugia (Kenyon et al. 2009).

The study period (April to September 2013) corresponds to the end of the rainy season and the early dry season in Northeast Brazil (Vilela et al. 2008). In these months, gastrointestinal nematode parasitism is higher in sheep and $H$. contortus represents more than $80 \%$ of the nematode population in the flock (Souza et al. 2013). This condition was decisive for the choice of the experiment execution period.

The volume and regularity of rainfall this year were atypical, where a low rainfall occurred in every month of the study. The low rainfall may have influenced the decline of the first epg (5th April to 26th May). A more profound decline in G-EsNano and G-Lev epg curves was apparent and differed significantly from the negative control. The epg peak in the sixth visit (June 29th) can be explained by the final rainy period, when the epg is high (Costa et al. 2009), but this increase was significantly more pronounced in the negative control group. Moreover, EsNano was able to maintain the epg of G-EsNano similar to the epg in the positive control group at all visits, except on April 22th and June 12th. The EsNano AH effect was also demonstrated for Eucalyptus staigeriana encapsulated oil, which was used against sheep GIN in a controlled test (Mesquita et al. 2013).

Although there was no significant difference in the number of animals treated between groups $(P>0.05)$, on June 29th and July 16th, the number of animals treated in G-EsNano was twice the number of animals treated in G-Lev; however the percentage of treated animals declined with subsequent visits while the G-Lev group maintained the same number of treated sheep.

There was no significant weight gain for any of the age groups treated with EsNano or levamisole or that were untreated $(P>0.05)$. This result may be attributed to the low food supply in the pasture, which is typical for periods with lower rainfall than average in semi-arid Northeastern Brazil. Even when sheep are exposed to supplementary feeding, Leask et al. (2013), in a study conducted in South Africa, did not observe a significant difference in weight gain among sheep treated with FAMACHA versus a conventional treatment with levamisole for twelve weeks during the summer and autumn seasons.

The combination of herbal medicines and FAMACHA minimizes the use of synthetic anthelmintics and maintains GIN populations in refugia. However, the survival of GIN populations at higher than acceptable levels requires a balance between the population in refugia, established by the new approach, and the potential adverse consequences of excessive parasitism (Besier 2012). This study demonstrated that levamisole may be replaced by EsNano, as they demonstrated equivalent anthelmintic effects. Further studies evaluating phytotherapy and FAMACHA in the rainy season are required to confirm the powerful effects of this combination in times of high pasture infestation.

Acknowledgements.- The authors would like to thank Programa de Apoio a Projetos Institucionais com a Participação de Recém-Doutores (PRODOC) / Coordenação de Aperfeiçoamento de Pessoal de Nível Superior (CAPES) for their financial support (AUX-PE-PRODOC 2717/2010) and CAPES for the scholarship. Dr. Bevilaqua was supported by a grant from Conselho Nacional de Desenvolvimento Científico e Tecnológico (303018/2013-5).

Conflicts of interest.- The authors declare that they have no conflicts of interest.

\section{REFERENCES}

Acharya J., Hildreth M.B. \& Reese R.N. 2014. In vitro screening of forty medicinal plant extracts from the United States Northern Great Plains for anthelmintic activity against Haemonchus contortus. Vet. Parasitol. 201:75-81.

Akkari H., Jebali J., Gharbi M., Mhadhbi M., Awadi S. \& Darghouth M.A. 2013. Epidemiological study of sympatric Haemonchus species and genetic characterization of Haemonchus contortus in domestic ruminants in Tunisia. Vet. Parasitol. 193:118-125.

Balan V. \& Verestiuc L. 2014. Strategies to improve chitosan hemocompatibility: a review. Eur. Polym. J. 53:171-188. 
Bath G.F. \& Van Wyk J.A. 2009. The Five Point Check $^{\odot}$ for targeted selective treatment of internal parasites in small ruminants. Small Rumin. Res. 86:6-13.

Besier R.B. 2012. Refugia-based strategies for sustainable worm control: Factors affecting the acceptability to sheep and goat owners. Vet. Parasitol. 186:2-9.

Cabaret J. 2008. Pro and cons of targeted selective treatment against digestive-tract strongyles of ruminants. Parasite 15:506-509.

Cabaret J. 2014. Reliable Phenotypic evaluations of anthelmintic resistance in herbivores: how and when should they be done?, p.1-26. In: Quick W. (Ed.), Anthelmintics: clinical pharmacology uses in veterinary medicine and efficacy. Nova Science Publisher, New York.

Ceará 2011. Perfil Básico Municipal 2011: Solonópole. <http://www.ipece.ce.gov.br/publicacoes/perfil_basico/pbm-2011/Solonopole.pdf> Accessed on Jan. 30, 2016.

Costa V.M.M., Simões S.V.D. \& Riet-Correa F. 2009. Doenças parasitárias em ruminantes no semi-árido brasileiro. Pesq. Vet. Bras. 29:563-568.

Dash M., Chiellini F., Ottenbrite R.M. \& Chiellini E. 2011. Chitosan: a versatile semi-synthetic polymer in biomedical applications. Prog. Polym. Sci. 36:981-1014.

Gordon H.M. \& Whitlock H.V. 1939. A new technique for counting nematode eggs in sheep faeces. J. Counc. Sci. Ind. Res. 12:50-52.

Grando T.H., De Sá M.F., Baldissera M.D., Oliveira C.B., De Souza M.E., Raffin R.P., Santos R.C.V., Domingues R., Minho A.P., Leal M.L.R. \& Monteiro S.G. 2015. In vitro activity of essential oils of free and nanostructured Melaleuca alternifolia and of terpinen-4-ol on eggs and larvae of Haemonchus contortus. J. Helminthol. 22:1-6.

Hasegawa T., Takano F., Takata T., Niiyama M. \& Ohta T. 2008. Bioactive monoterpene glycosides conjugated with gallic acid from the leaves of Eucalyptus globulus. Phytochemistry 69:747-753.

Herculano E.D., Paula H.C.B., Figueiredo E.A.T., Dias F.G.B. \& Pereira V.A. 2015. Physicochemical and antimicrobial properties of nanoencapsulated Eucalyptus staigeriana essential oil. LWT - Food Sci. Technol. 61:484491.

Kenyon F., Greer A.W., Coles G.C., Cringoli G., Papadopoulos E., Cabaret J., Berrag B., Varady M., Van Wyk J.A., Thomas E., Vercruysse J. \& Jackson F. 2009. The role of targeted selective treatments in the development of refugia-based approaches to the control of gastrointestinal nematodes of small ruminants. Vet. Parasitol. 164:3-11.

Kochapakdee S., Pandey V.S., Pralomkarm W., Choldumrongkul S., Ngampongsai W. \& Lawpetchara A. 1995. Anthelmintic resistance in goat in southern Thailand. Vet. Rec. 137:124-125.

Leask R., Bath G.F. \& Van Wyk J.A. 2013. The effect of application of the FAMACHA $^{\oplus}$ system on selected production parameters in sheep. Small Rumin. Res. 110:1-8.

Lifschitz A., Ballent M., Virkel G., Sallovitz J. \& Lanusse C. 2014. Accumulation of monepantel and its sulphone derivative in tissues of nematode location in sheep: pharmacokinetic support to its excellent nematodicidal activity. Vet. Parasitol. 203;120-126.

Macedo I.T.F., Bevilaqua C.M.L., Oliveira L.M.B., Camurça-Vasconcelos A.L.F., Vieira L.S., Oliveira F.R., Queiroz-Júnior E.M., Tomé A.R. \& Nascimento N.R.F. 2010. Anthelmintic effect of Eucalyptus staigeriana essential oil against goat gastrointestinal nematodes. Vet. Parasitol. 173:93-98.

Mesquita M.A., Silva Júnior J.B., Panassol A.M., Oliveira E.F., Camurça-Vasconcelos A.L.F., Paula H.C.B. \& Bevilaqua C.M.L. 2013. Anthelmintic activity of Eucalyptus staigeriana encapsulated oil on sheep gastrointestinal nematodes. Parasitol. Res. 112:3161-3165.

Molento M.B., Gavião A.A., Depner R.A. \& Pires C.C. 2009. Frequency of treatment and production performance using the FAMACHA method compared with preventive control in ewes. Vet. Parasitol. 162:314-319.

Molento M.B., Tasca C., Gallo A., Ferreira M., Bononi R. \& Stecca E. 2004. Método FAMACHA como parâmetro clínico individual de infecção por Haemonchus contortus em pequenos ruminantes. Ciência Rural 34: 1139-1145.
Morgan E.R. \& Van Dijk J. 2012. Climate and the epidemiology of gastrointestinal nematode infections of sheep in Europe. Vet. Parasitol. 189:814.

Paula H.C.B., Sombra F.M., Cavalcante R.F., Abreu F.O.M.S. \& De Paula R.C.M. 2011. Preparation and characterization of chitosan/cashew gum beads loaded with Lippia sidoides essential oil. Mat. Sci. Eng. C 31: 173-178.

Ribeiro J.C., Ribeiro W.L.C., Camurça-Vasconcelos A.L.F., Macedo I.T.F., Dos Santos J.M.L., Paula H.C.B., Araújo-Filho J.V., Magalhães R.D. \& Bevilaqua C.M.L. 2014. Efficacy of free and nanoencapsulated Eucalyptus citriodora essential oils on sheep gastrointestinal nematodes and toxicity for mice. Vet. Parasitol. 204:243-248.

Ribeiro W.L.C., Camurça-Vasconcelos A.L.F., Macedo I.T.F., Dos Santos J.M. L., Araújo-Filho J.V., Ribeiro J.C., Pereira V.A., Viana D.A., De Paula H.C.B. \& Bevilaqua C.M.L. 2015. In vitro effects of Eucalyptus staigeriana nanoemulsion on Haemonchus contortus and toxicity in rodents. Vet. Parasitol. 212:444-447.

Ribeiro W.L.C., Macedo I.T.F., Dos Santos J.M.L., De Oliveira E.F., Camurça-Vasconcelos A.L.F., De Paula H.C.B. \& Bevilaqua C.M.L. 2013. Activity of chitosan-encapsulated Eucalyptus staigeriana essential oil on Haemonchus contortus. Exp. Parasitol. 135:24-29.

Robles E., Villar E., Alatorre-Meda M., Burboa M.G., Valdez M.V., Taboada P. \& Mosquera V. 2013. Effects of the hydrophobization on chitosan-insulin nanoparticles obtained by an alkylation reaction on chitosan. J. Appl. Polym. Sci., 129:822-834.

Sandoval-Castro C.A., Torres-Acosta J.F.J., Hoste H., Salem A.Z.M. \& Chan-Pérez J.I. 2012. Using plant bioactive materials to control gastrointestinal tract helminths in livestock. Anim. Feed Sci. Tech. 176:192-201.

Sandoval-Júnior P. 2011. Manual de Criação de Caprinos e Ovinos. Codevasf, Brasília.

Scott I., Pomroy W.E., Kenyon P.R., Smith G., Adlington B. \& Moss A. 2013. Lack of efficacy of monepantel against Teladorsagia circumcincta and Trichostrongylus colubriformis. Vet. Parasitol. 198:166-171.

Shahavi M.H., Hosseini M., Jahanshahi M., Meyer R.L. \& Darzi G.N. 2015. Evaluation of critical parameters for preparation of stable clove oil nanoemulsion. Arabian J. Chem. In publication. doi:10.1016/j.arabjc.2015.08.024

Souza M.F., Pimentel-Neto M., Pinho A.L.S., Silva R.M., Farias A.C.B. \& Guimarães M.P. 2013. Seasonal distribution of gastrointestinal nematode infections in sheep in a semiarid region, northeastern Brazil. Revta Bras. Parasitol. Vet. 22;351-359.

Ueno H. \& Gonçalves P.C. 1988. Manual para o Diagnóstico das Helmintoses de Ruminantes, 4th ed. Japan International Cooperation Agency, Tokyo.

Underwood C. \& Van Eps A.W. 2012. Nanomedicine and veterinary science: the reality and the practicality. Vet. J. 193:12-23.

Van den Brom R., Moll L., Kappert C. \& Vellema P. 2015. Haemonchus contortus resistance to monepantel in sheep. Vet. Parasitol. 209:278-280.

Vatta A.F., Letty B.A., Van der Linde M.J., Van Wijk E.F., Hansen J.W. \& Krecek R.C. 2001. Testing for clinical anaemia caused by Haemonchus spp. in goats farmed under resource-poor conditions in South Africa using an eye colour chart developed for sheep. Vet. Parasitol. 99:1-14.

Vieira V.D., Vilela V.L.R., Feitosa T.F., Athayde A.C.R., Azevedo S.S., Souto D.V.O., Silveira G.L. \& Melo R.B. 2014. Sheep gastrointestinal helminthiasis in the Sertão region of Paraíba State, northeastern Brazil: prevalence and risk factors. Revta Bras. Parasitol. Vet. 23:488-494.

Vilela V.L.R., Feitosa T.F., Linhares E.F., Athayde A.C.R., Molento M.B. \& Azevedo S.S. 2012. FAMACHA ${ }^{\odot}$ method as an auxiliary strategy in the control of gastrointestinal helminthiasis of dairy goats under semiarid conditions of Northeastern Brazil. Vet. Parasitol. 190:281-284.

Vilela V.L.R., Solano G.B., De Araujo M.M., De Sousa R.V., Da Silva W.A., Feitosa T.F. \& Athayde A.C.R. 2008. Ensaios preliminares para validação do método FAMACHA ${ }^{\odot}$ em condições de Semi-Árido paraibano. Revta Bras. Parasitol. Vet. 7:154-157. 